\title{
El Patronato del Real Alcázar de Sevilla cumple 25 años
}

\begin{abstract}
El Real Alcázar Sevilla, que se gestiona a través de un patronato dependiente del Ayuntamiento de la ciudad, fue creado hace 25 años y tiene entre sus cometidos todo lo relacionado con la conservación y el uso del Alcázar y de la Casa Consistorial. A lo largo de este cuarto de siglo el Patronato se ha perfilado como una herramienta ágil de gestión. En este aniversario, desde su interés por adaptarse a los nuevos tiempos, reflexiona y diseña las líneas maestras de su futuro y las comparten aquí.
\end{abstract}

Isabel Rodríguez Rodríguez | directora-conservadora del Real Alcázar de Sevilla

URL de la contribución <http://www.iaph.es/revistaph/index.php/revistaph/article/view/4452>

El Patronato del Real Alcázar de Sevilla (en adelante PRAS) está administrado por el Consejo, la Comisión Ejecutiva respecto a sus órganos colegiados, y por el presidente, Alcaide y Dirección, como unipersonales.

Durante su trayectoria, el Alcázar de Sevilla ha pasado de ser un monumento a un elemento simbólico para la ciudad y uno de los recursos turísticos más importantes para Sevilla. Desde la creación del Patronato, la venta de entradas ha cubierto las necesidades económicas para su correcto mantenimiento tanto de su plantilla, como de las acciones dirigidas a su conservación. Se ha perfilado como una herramienta ágil de gestión desde los años 90 del siglo pasado hasta la actualidad.

Los cambios tecnológicos, sociales, económicos y de todo tipo en nuestra sociedad, desde la creación del Patronato hasta el día de hoy, hacen necesario su adaptación a los tiempos actuales. A este devenir universal, se une la incorporación de las nuevas tecnologías a la gestión de los monumentos, el desarrollo de la administración pública, la llegada masiva de visitantes a los grandes iconos culturales, y la nueva situación referida a la seguridad. Todo esto hace aconsejable adaptar el Alcázar a los tiempos actuales y diseñar el futuro, al menos sus líneas maestras. Igualmente es imprescindible el análisis y revisión de toda la normativa interna de uso, así como la elaboración de una normativa para la visita turística y la modernización de la carta de servicios.

Además de la urgente necesidad de adaptar su plantilla a las condiciones actuales y crear una estructura pluri-

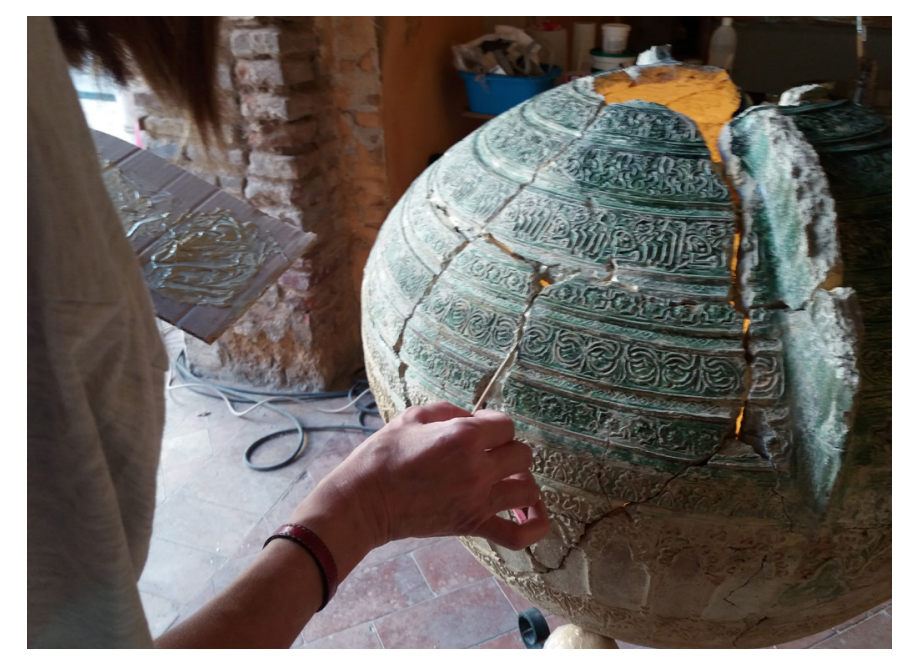

Restauración de piezas arqueológicas | foto Real Alcázar de Sevilla

disciplinar acorde con los nuevos tiempos, el espectacular aumento de visitantes ha obligado al PRAS a preparar la acogida y programar la entrada con antelación, usando las nuevas tecnologías. Queda pendiente la recuperación del espacio de entrada al Alcázar, y a la par acondicionar el acceso ofreciendo una mayor seguridad y confort al visitante. Se hace imprescindible la ejecución de un proyecto patrimonial que además dé soluciones al acceso a través de la puerta del León ${ }^{1}$.

Respecto a la conservación, el Alcázar tiene que desarrollar la conservación preventiva en todos sus elementos y seguir restaurando aquellos que por su estado de conservación requieran un proyecto de restauración. Para mejorar la gestión en conservación e incorporar el riesgo a nuestro análisis, estamos involucrados en la 
elaboración del Plan de Conservación ${ }^{2}$ preventiva del Alcázar que esperemos siente las bases de actuación en esta materia para los próximos años.

Entendida la delimitación del Alcázar no sólo referida a la parcela catastral titularidad del Ayuntamiento de Sevilla, sino en un sentido amplio, representa para Sevilla una oportunidad única aumentar los espacios visitables y dotar al Alcázar de servicios turísticos inexistentes, que son indispensables en cualquier elemento visitable. La apertura de la cripta excavada y conservada y su puesta en valor permitiría mostrar los resultados de las excavaciones arqueológicas realizadas hace años. Revelar los orígenes del asentamiento en este lugar de la ciudad y seguir investigando y mostrando a la sociedad es una responsabilidad de los gestores patrimoniales. Su gestión desde el PRAS garantizaría su conservación y disfrute por parte de visitantes y sevillanos.

Las últimas intervenciones arqueológicas paramentales ${ }^{3}$ llevadas a cabo en las casas que conforman el Patio de Banderas, en especial las 7-8 y la n. ${ }^{\circ} 2$ albergan elementos del palacio de los siglos X-XI. De igual interés patrimonial es la puerta y el lienzo de muralla existente en la casa . $^{\circ} 12$ del mencionado patio. Se hace necesario ampliar la delimitación de BIC para adecuar la figura de protección a los nuevos hallazgos arqueológicos.

En materia de difusión, el PRAS debe acometer la especialización cultural, con actividades dirigidas a la población en general y actuaciones diseñadas para la población local. En este ámbito se han producido avances en los últimos años, con un incremento reseñable de visitantes locales.

\section{NOTAS}

1. Un discurso coherente de acuerdo con la idiosincrasia del Alcázar, y su tipología esencial de palacio medieval, hace muy forzado el acceso a través del patio de Banderas. EI PRAS encargó en su día un proyecto básico al profesor Francisco Reina.

2. Actualmente se está elaborando el plan de Conserva- ción Preventiva con la Fundación Santa María la Real, adjudicataria del proyecto.

3. Todas estas intervenciones han sido llevadas a cabo por Miguel Ánge Tabales Rodríguez y su equipo (ver revista $\mathrm{PH}$ n. ${ }^{\circ}$ 93, 2018: www.iaph.es/revistaph/index.php/ revistaph/article/view/4114).

\section{BIBLIOGRAFÍA}

- ESTATUtOS del Patronato del Real Alcázar y de la Casa Consistorial (1995). Sevilla: Patronato del Real Alcázar y de la Casa Consistorial, 1995

- LINEROS ROMERO, R. (2003) Carmona (Sevilla): tener como referencia continua el valor social del patrimonio histórico. Revista $P H$, n. ${ }^{\circ} 42,2003$, p. 103

- PÉREZ FERRER, J.C.; FERNÁNDEZ AGUILERA. S. (2004) La restauración de los portalones y ventanas del Patio de las Doncellas del Palacio de Pedro I en el Real Alcázar de Sevilla. Apuntes del Alcázar, n. ${ }^{\circ}$ 5, 2004

- SALMERÓN ESCOBAR P.; TROITIÑO M. A. (2018) Estudio sobre el Funcionamiento de la visita pública del Real Alcázar de Sevilla. Bases para la reordenación funcional del Conjunto monumental. Patronato del Real Alcázar (Inédito)

- tABAles Rodríguez, M. A. (2017) Aproximación arqueológica a la puerta del León del Alcázar de Sevilla. Apuntes del Alcázar, n. ${ }^{\circ}$ 18, 2017

- BERMUDO BORREGO, R.; LLANOS SISO, V. (2015) Plan Especial de Protección del Sector 6. Real Alcázar del Conjunto Histórico de Sevilla. Apuntes del Alcázar de Sevilla, n. ${ }^{\circ}$ 16, 2015, pp. 8-51 